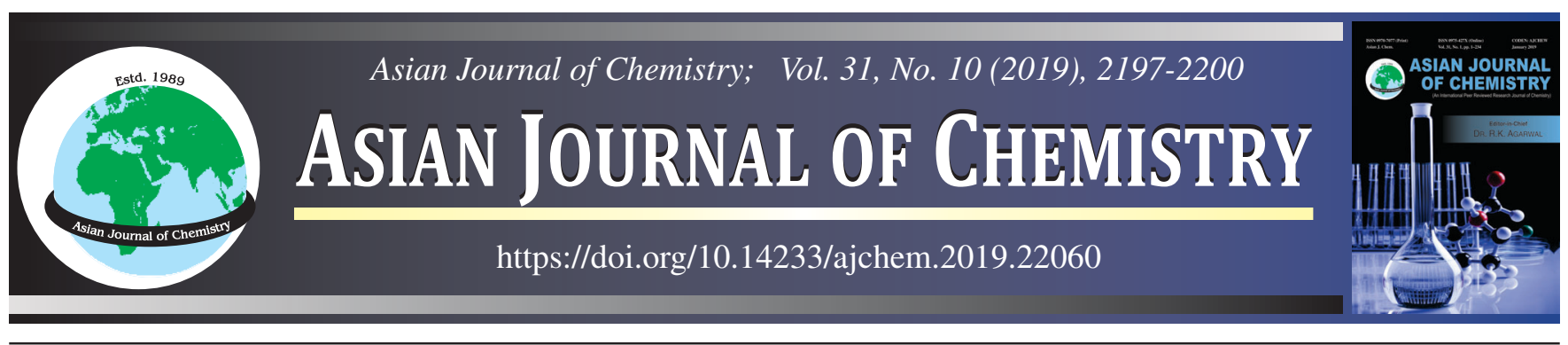

\title{
Zinc Oxide Supported onto Biogenic Silica from Gigantochloa atroviolacea Leaves: Preparation, Characterization and Antibacterial Activity
}

\author{
Elsa Sriwahyuni ${ }^{1, * \bullet}$, Anti Kolonial Prodjosantoso ${ }^{1, \bullet}$ and Dewi Sasmita ${ }^{1,2, \bullet}$
}

${ }^{1}$ Department of Chemistry, Yogyakarta State University, Yogyakarta, Indonesia

${ }^{2}$ Department of Chemistry Education, State Institute for Islamic Studies, West Sumatra, Indonesia

*Corresponding author: E-mail: elsasriwahyuni.2017@student.uny.ac.id

Received: 9 March 2019;

Accepted: 30 April 2019;

Published online: 30 August 2019;

AJC-19522

Bamboo rod is a well known raw material utilized to make houses, papers, handicrafts, chopsticks and medicines. On the other hand, the utilzation of leaves, which are often considered as garbages, receive less attentions. Even though, bamboo leaves are good sources of $\mathrm{SiO}_{2}$ or silica. This work reports the preparation of zinc oxide $(\mathrm{ZnO})$ supported onto biogenic silica $\left(\mathrm{SiO}_{2}\right)$ from leaves of Gigantochloa atroviolacea, characterization and the antibacterial activities of $\mathrm{ZnO} @ \mathrm{SiO}_{2}$ against Staphylococcus epidermidis. The $\mathrm{ZnO}$ was supported | onto biogenic $\mathrm{SiO}_{2}$ by using impregnation method of $\mathrm{SiO}_{2}$ in zinc salt $\left[\mathrm{Zn}\left(\mathrm{NO}_{3}\right)_{2} \cdot 6 \mathrm{H}_{2} \mathrm{O}\right]$ solution. A combination XRD and SEM-EDX techniques were used to confirm the formation of $\mathrm{ZnO}$ on ${\mathrm{ZnO} @ \mathrm{SiO}_{2} \text {. Investigations indicate that the as prepared } \mathrm{ZnO} @ \mathrm{SiO}}_{2}$ revealed significant antibacterial activity against Staphylococcus epidermidis bacterial strain

Keywords: $\mathrm{ZnO} @ \mathrm{SiO}_{2}$, Biogenic silica, Gigantochloa atroviolacea, Staphylococcus epidermidis.

ᄂ - - - - - - - - - - - - - - - - - - - - - - - - - - - -

\section{INTRODUCTION}

Microorganisms may give beneficial or harmful effects on the environment regarding to the human being. It is necessary to control microorganisms harmful effects by inhibiting their growth. Antimicrobial agents are chemical compounds having potential to inactivate or inhibit the growth of microorganism [1]. The antimicrobial agents have vast applications in various fields including food preservation and packaging, medicine, water disinfection, textile fabrics and hospital implants [2,3].

Zinc oxide is one of attractive metal oxides and has been used as an active constituent in ointment, creams and lotions for skin treatments owing to its antibacterial properties [4-6]. Zinc oxide is also widely used to treat dermatitis, itching due to eczema, diaper rash and acne [7]. It is used in products such as baby powder and barrier creams to treat diaper rashes, calamine cream, antidandruff shampoos and antiseptic ointments [8,9].

Zinc oxide nanoparticles indicate more antimicrobial activities than large particles, since the high surface-to-volume ratio of nanoparticles allows for better interaction with bacteria $[10,11]$. Zinc oxide nanoparticles have been shown to have a wide range of antibacterial activities including major food- borne pathogens like Escherichia coli, Salmonella, Listeria monocytogenes and Staphylococcus aureus. The Staphylococcus aureus family contributes to $65-90 \%$ of all Staphylococci recovered from human aerobic flora. It has developed resistance to many common antibiotics such as methicillin, novobiocin, clindamycin and benzyl penicillin [12].

Currently there is a little information available on their antibacterial effect against species of Staphylococcus epidermidis [13-15]. Staphylococcus epidermidis is a Gram-positive and a true opportunistic pathogen. It is one of the leading pathogens of nosocomial infections. Those most susceptible to infection are intravenous drug users, newborns, elderly and those using catheters or other artificial appliances [16].

Zinc is an essential element for microorganisms and higher organisms because it involved in many vital cellular reactions at its low endogenous concentrations [17-19]. Zinc concentration is regulated under physiological conditions by several transporters, so that $\mathrm{Zn}^{2+}$ ions are essentially non-toxic to higher organisms [20,21]. Homeostasis regulates zinc uptake by cells, but it does not control zinc adsorption to cell membranes however, increase in $\mathrm{Zn}^{2+}$ concentrations above optimal levels perturbs $\mathrm{Zn}^{2+}$ homeostasis and allows entry of $\mathrm{Zn}^{2+}$ inside cells,

This is an open access journal, and articles are distributed under the terms of the Attribution 4.0 International (CC BY 4.0) License. This license lets others distribute, remix, tweak, and build upon your work, even commercially, as long as they credit the author for the original creation. You must give appropriate credit, provide a link to the license, and indicate if changes were made. 
so that zinc starts being cytotoxic to prokaryotes above a concentration of $10^{-4} \mathrm{M}$. Therefore, $\mathrm{Zn}^{2+}$ displays an antimicrobial activity and could act as either antibacterial or antifungal agent $[22,23]$.

In dermatological products, zinc ions are interesting biocides and/or antimicrobial preservatives provided that high enough concentrations of $\mathrm{Zn}^{2+}$ are generated. The previously mentioned zinc salts can be simply dissolved in the aqueous medium. An alternative is solid powder such as $\mathrm{ZnO}$ particles that release $\mathrm{Zn}^{2+}$ in the aqueous medium. It is indeed recognized that part of the antimicrobial activity of $\mathrm{ZnO}$ particles originates from their ability to partially dissolve in aqueous media. Release of $\mathrm{Zn}^{2+}$ would contribute to the global antimicrobial properties of this inorganic powder [24,25].

However, zinc oxide nanoparticles are much more effective in suppression of microorganism growth. Furthermore, at nanoscale the properties of $\mathrm{ZnO}$ particles are widely changed, enhancing their efficacy in inhibiting the growth of bacteria $[5,26,27]$. The antimicrobial potential of metal oxide nanoparticles has been recognized to their smaller size and higher surface to volume ratio, which enables them to closely bind with microbial strain but it does not due to the discharge of metal ions in solution [5,28].

Nanotechnology is getting advancement particularly the potential to prepare metal oxide nanomaterials of specific shape and size which leads it in the development of new antibacterial agents [29,30]. Different methods have been used to synthesize nanoparticles like sol-gel method [31], surfactant mediated method [32], deposition-precipitation method [33], anodization method [34], wet-oxidation method [35], microwaveassisted combustion [36], electrodeposition and sonication [37]. Zinc oxide nanoparticles synthesized by any of these methods are used against bacterial strains by adopting various protocols. The catalytic activity and antimicrobial properties of nanoparticles can be enhanced by doping the nanoparticles with various methods. In this study, we have designed method to prepare zinc oxide nanoparticles supported onto a stablewide surface biogenic $\mathrm{SiO}_{2}$ extracted from the leaves of Gigantochloa atroviolacea. The evaluation of antibacterial effects of $\mathrm{ZnO}$ against Staphylococcus epidermidis is reported.

\section{EXPERIMENTAL}

Biogenic silica was isolated by calcining $100 \mathrm{~g}$ of dry Gigantochloa atroviolacea leaves at $650{ }^{\circ} \mathrm{C}$ for $4 \mathrm{~h}$, followed by air cooling and washing with $0.1 \mathrm{M} \mathrm{HCl}$ solution. The $\mathrm{ZnO} @ \mathrm{SiO}_{2}$ was prepared by mixing $1.9848 \mathrm{~g}$ of biogenic silica and $0.0152 \mathrm{~g}$ of zinc nitrate $\left[\mathrm{Zn}\left(\mathrm{NO}_{3}\right)_{2} \cdot 6 \mathrm{H}_{2} \mathrm{O}\right.$ (Merck)] $(0.25$ mol \% zinc to silica) in $5 \mathrm{~mL}$ of distilled water. The mixture was then stirred for $2 \mathrm{~h}$ at which time $5 \mathrm{~mL}$ absolute ethanol was added and the solid was isolated by filtration and air dried. The dry sample was then calcined at $800{ }^{\circ} \mathrm{C}$ for $4 \mathrm{~h}$, resulting in biogenic silica supported zinc oxide $\left(\mathrm{ZnO} @ \mathrm{SiO}_{2}\right)$. The catalysts with $0.5 \mathrm{~mol} \%$ of zinc were prepared by the same procedure except using $0.0304 \mathrm{~g}$ of zinc nitrate.

The $\mathrm{ZnO} @ \mathrm{SiO}_{2}$ photocatalysts were characterized by X-ray diffraction (XRD Lab-X Type 6000 Shimadzu, Japan) using $\mathrm{Cu} \mathrm{K} \alpha$ radiation $(\lambda=1.5418 \AA$ ) over the angular range $10^{\circ} \leq 2 \theta \leq 90^{\circ}$ at a scan speed of $0.02 \mathrm{deg} \mathrm{s}^{-1}$. Scanning electron micrographs were measured using a Jeol JED-2300 instrument.
Antibacterial activity of $\mathrm{ZnO} @ \mathrm{SiO}_{2}$ was studied against a bacterial strain Staphylococcus epidermidis. The bacterial culture, nutrient broth (Oxoid, UK) $100 \mathrm{~mL}$ was prepared in Erlenmeyer flask contained glass beads. The $\mathrm{pH}$ of broth was adjusted to 7.4 by addition of buffer solution, and autoclaved at $121^{\circ} \mathrm{C}$ for $15 \mathrm{~min}$. The mixture was allowed to cool in open air. The broth was inoculated with $100 \mu \mathrm{L}$ Staphylococcus epidermidis form stored bacterial culture. Growth medium was incubated in a shaker at $37^{\circ} \mathrm{C}$ for $24 \mathrm{~h}$ to get $5 \times 10^{9}$ cells per mL.

Nutrient was prepared by mixing agar in distilled water. The nutrient and $10 \mathrm{~mm}$ discs of wicks paper were sterilized in autoclave and allowed to cool in air. The nutrient was inoculated with $50 \mu \mathrm{L}$ fresh Staphylococcus epidermidis culture and sterilized discs were poured with synthesized $\mathrm{ZnO} @ \mathrm{SiO}_{2}$ and spread in petri dishes with positive control in the other side. The petri-dishes incubated at $37^{\circ} \mathrm{C}$ for $24 \mathrm{~h}$. Zones were measured with zone reader. The different levels of zone of inhibition were measured every $3 \mathrm{~h}$ for $24 \mathrm{~h}$ for determining the antimicrobial activity of synthesized $\mathrm{ZnO} @ \mathrm{SiO}_{2}$.

\section{RESULTS AND DISCUSSION}

The study of $\mathrm{ZnO} @ \mathrm{SiO}_{2}$ prepared using biogenic silica from Gigantochloa atroviolacea was reported in this work. The $\mathrm{ZnO} @ \mathrm{SiO}_{2}$ was also tested for antimicrobial activity against Staphylococcus epidermidis. The $\mathrm{ZnO} @ \mathrm{SiO}_{2}$ was investigated by X-ray diffraction. Fig. 1 shows the XRD pattern for ZnO@ $\mathrm{SiO}_{2}$. The difractograms indicate the presence of $\mathrm{SiO}_{2}(\mathrm{Fig}$. 1a-b). The weak-broad XRD line of (002) (Fig. 1b) can be considered as small-amorf satelites of ZnO (JCPDS No. 00-0361451). The crystal nature of $\mathrm{ZnO}$ is wurtzite hexagonal which is similar as reported by Darroudi et al. [38] and Zak et al. [39].

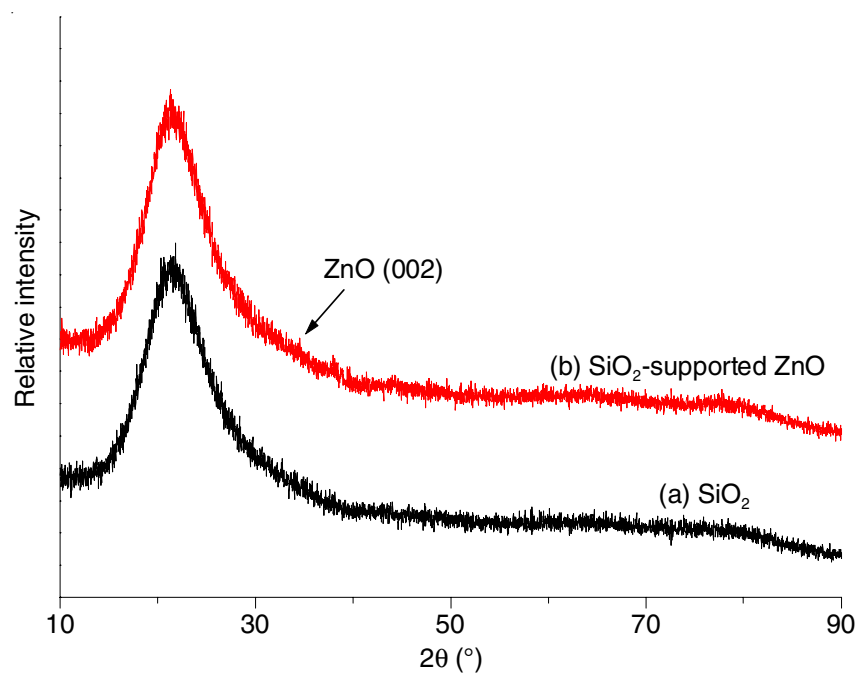

Fig. 1. X-ray diffraction pattern of (a) $\mathrm{SiO}_{2}$ and (b) $\mathrm{ZnO} @ \mathrm{SiO}_{2}$

In order to verify the results of X-ray diffraction analysis, $\mathrm{ZnO}$ on the surface of $\mathrm{SiO}_{2}$ were examined by TEM analysis. From TEM analysis (Fig. 2), $\mathrm{ZnO}$ is observed as rounded in shape and is observed having diameter about $200 \mathrm{~nm}$, which can be catagorized as nanoparticles. However, Santhaveesuk et al. [40] successfully prepared smaller $\mathrm{ZnO}$ nanoparticles, that are $47 \mathrm{~nm}$ in size, via the coprecipitation method using zinc nitrate and sodium hydroxide as raw materials. 


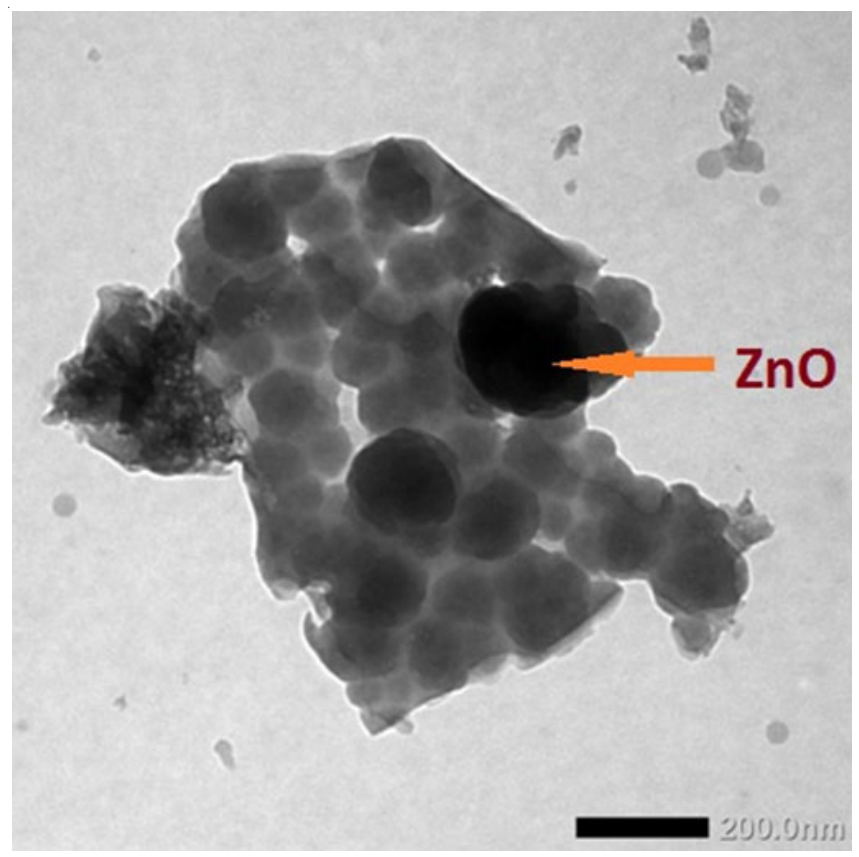

Fig. 2. TEM micrograph of $\mathrm{ZnO} @ \mathrm{SiO}_{2}$. The arrow indicates $\mathrm{ZnO}$ crystallites

The SEM micrograph represents the morphology of $\mathrm{ZnO} @ \mathrm{SiO}_{2}$ (Fig. 3). The $\mathrm{SiO}_{2}$ shows irregular form and surface and has a size of between 4 to $30 \mu \mathrm{m}$. Holes with the diameter of around $2 \mu \mathrm{m}$ are observed over the surfaces. The presence of $\mathrm{ZnO}$ is difficult to be located, but it is believed that the iregular in shape of $\mathrm{ZnO}$ is placed on the surface of $\mathrm{SiO}_{2}$ and this is supported by the EDX analysis (Fig. 4). Fig. 4 confirms the presence of $\mathrm{ZnO}$ on the sample with sharp signals of $\mathrm{Zn}$ $\left(\mathrm{ZnL} \alpha_{1}, \mathrm{ZnK} \alpha_{1}, \mathrm{ZnK} \beta_{1}\right)$, along with $\mathrm{O}$ and Si lines. An EDX analysis indicates that the proportion of $\mathrm{Zn}$ to $\mathrm{Si}$ is expected.

The antibacterial effect of prepared $\mathrm{ZnO} @ \mathrm{SiO}_{2}$ is studied on Staphylococcus epidermidis. The $\mathrm{ZnO} @ \mathrm{SiO}_{2}$ inhibition zone value and the control antibiotic chlorofenicol are given in Table-1.

The zone of inhibition of $\mathrm{ZnO} @ \mathrm{SiO}_{2}$ is about $50 \%$ compared to the control antibiotic chlorophenicol. This indicates that $\mathrm{ZnO} @ \mathrm{SiO}_{2}$ is quite powerful to inhibit the development of Staphylococcus epidermidis. The inhibition is maximum

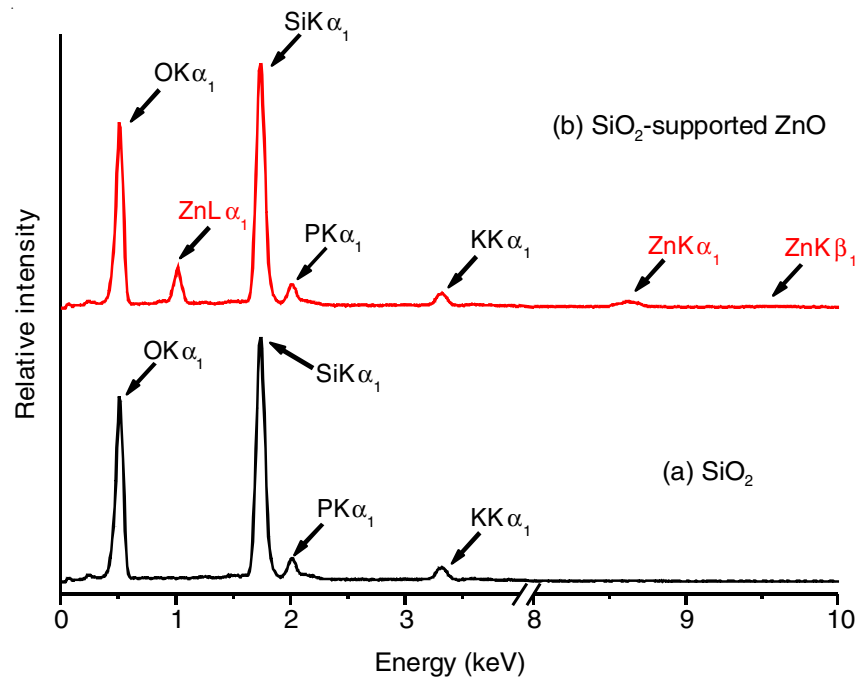

Fig. 4. EDX pattern of (a) $\mathrm{SiO}_{2}$ support and (b) $\mathrm{ZnO} @ \mathrm{SiO}_{2}$

\begin{tabular}{cccc}
\multicolumn{5}{c}{ TABLE-1 } \\
\multicolumn{4}{c}{$\begin{array}{c}\text { ZnO@ } \\
\text { CONTROL } \text { SiNHIBITION ZONE AND THE } \text { ANTIBIOTIC CHLOROFENICOL }\end{array}$} \\
\hline \multirow{2}{*}{$\begin{array}{c}\text { Observation } \\
\text { time (h) }\end{array}$} & $\begin{array}{c}\text { Chlorofenicol } \\
\text { (control) }\end{array}$ & $\mathrm{SiO}_{2}$ & $\mathrm{ZnO} @ \mathrm{SiO}_{2}$ \\
\hline 3 & 18.7 & 0 & 9.3 \\
6 & 18.0 & 0 & 9.1 \\
9 & 19.7 & 0 & 8.2 \\
12 & 18.6 & 0 & 8.0 \\
15 & 19.4 & 0 & 8.5 \\
18 & 21.2 & 0 & 8.0 \\
21 & 20.4 & 0 & 7.9 \\
24 & 19.9 & 0 & 7.8 \\
\hline
\end{tabular}

after $3 \mathrm{~h}$ of the introduction of $\mathrm{ZnO} @ \mathrm{SiO}_{2}$. The $\mathrm{SiO}_{2}$ is absent in bacteria inhibition, and this indicates that bacteria inhibitions is occured as result of $\mathrm{ZnO}$ supported on the surface of $\mathrm{SiO}_{2}$. Hence, green synthesis of $\mathrm{SiO}_{2}$ can also be used as good support for $\mathrm{ZnO}$ antibacterial agent.

\section{Conclusion}

The $\mathrm{ZnO} @ \mathrm{SiO}_{2}$ nanoparticles have been synthesized and characterized. The characterization by using XRD, SEM, EDX
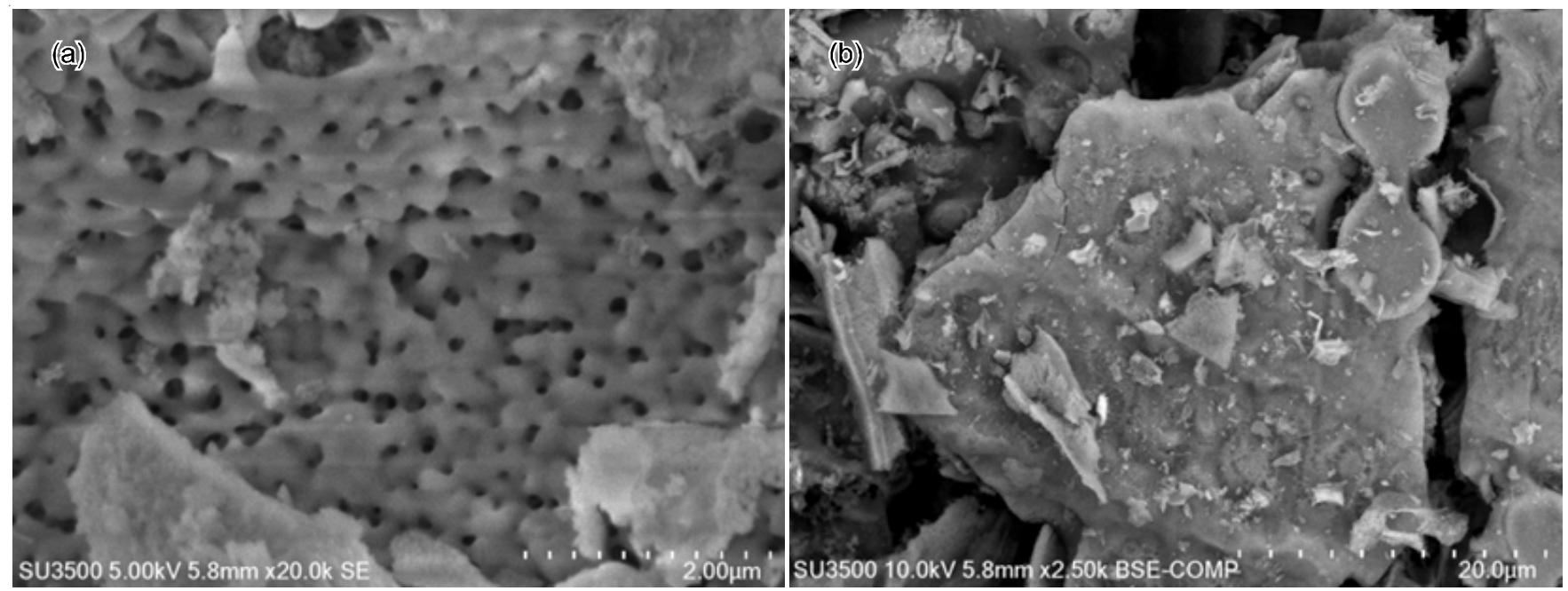

Fig. 3. SEM micrograph of synthesized $\mathrm{ZnO} @ \mathrm{SiO}_{2}$, (a) $20.000 \mathrm{X}$, and (b) $2.500 \mathrm{X}$ magnifications 
and TEM methods confirmed the formation of $\mathrm{ZnO} @ \mathrm{SiO}_{2}$. The zone of inhibition in the antimicrobial screening indicated that synthesized $\mathrm{ZnO} @ \mathrm{SiO}_{2}$ has efficient antimicrobial activity against Staphylococcus epidermidis.

\section{CONFLICT OF INTEREST}

The authors declare that there is no conflict of interests regarding the publication of this article.

\section{REFERENCES}

1. L.P. Silva, A.P. Silveira, C.C. Bonatto, I.G. Reis and P.V. Milreu, Silver Nanoparticles as Antimicrobial Agents: Past, Present, and Future, In: Nanostructures for Antimicrobial Therapy, Elsevier, Chap. 26, p. 577 (2017);

2. S. Abram, J. Gagnon, M. Priebe, N. Hérault and K.M. Fromm, Chim. Int. J. Chem., 72, 249 (2018); https://doi.org/10.2533/chimia.2018.249.

3. S. Remya, C. Mohan, C. Ravishankar, R. Badonia and T. Gopal, eds.: A.K. Haghi and E. Carvajal-Millan, Food Composition and Analysis: Methods and Strategies, CRC press, p. 377 (2014); https://doi.org/10.1201/b16843-22.

4. Y. Jiang, L. Zhang, D. Wen and Y. Ding, Mater. Sci. Eng. C, 69, 1361 (2016); https://doi.org/10.1016/j.msec.2016.08.044

5. Z. Emami-Karvani, Afr. J. Microbiol. Res., 5, 18 (2012).

6. S. Wang, J. Wu, H. Yang, X. Liu, Q. Huang and Z. Lu, J. Mater. Sci. Mater. Med., 28, 23 (2017); https://doi.org/10.1007/s10856-016-5837-8.

7. J.Y. Bae and S.N. Park, Int. J. Cosmet. Sci., 38, 550 (2016); https://doi.org/10.1111/ics.12318.

8. X. Zhang, L. Chen, Y. Sun, Y. Bai, B. Huang and K. Chen, Spectrochim. Acta A Mol. Biomol. Spectrosc., 193, 133 (2018); https://doi.org/10.1016/j.saa.2017.12.019.

9. L.C. Ann, S. Mahmud, S.K.M. Bakhori, A. Sirelkhatim, D. Mohamad, H. Hasan, A. Seeni and R.A. Rahman, AIP Conf. Proc., 1657, 100012 (2015); https://doi.org/10.1063/1.4915219.

10. T. Gordon, M. Kopel, J. Grinblat, E. Banin and S. Margel, J. Mater. Chem., 22, 3614 (2012); https://doi.org/10.1039/c2jm15510a.

11. K. Elumalai and S. Velmurugan, Appl. Surf. Sci., 345, 329 (2015); https://doi.org/10.1016/j.apsusc.2015.03.176.

12. D. Grace and A. Fetsch, Staphylococcus aureus-A Foodborne Pathogen: Epidemiology, Detection, Characterization, Prevention and Control: An Overview, Elsevier: Amsterdam, Chap. 1, pp. 3-10 (2018).

13. S. Fanny Chiat Orou, K.J. Hang, M. Thuya Thien, Y.L. Ying, L.C. Foh, N. Duong Ngoc Diem, B.H. Goh, S.Y. Pung and Y.F. Pung, J. Ind. Eng. Chem., 62, 333 (2018); https://doi.org/10.1016/j.jiec.2018.01.013.

14. A. Joe, S.H. Park, D.J. Kim, Y.J. Lee, K.H. Jhee, Y. Sohn and E.S.Y. Jang, J. Solid State Chem., 267, 124 (2018); https://doi.org/10.1016/j.jssc.2018.08.003.

15. E. ahin, S.J. Musevi and A. Aslani, Arab. J. Chem., 10, S230 (2017); https://doi.org/10.1016/j.arabjc.2012.07.027.

16. M. Otto, ed.: P. Fey, Staphylococcus epidermidis Pathogenesis, Staphylococcus epidermidis. In: Methods in Molecular Biology (Methods and Protocols), Humana Press, Totowa, NJ, vol. 1106 (2014).

17. J. Wyszkowska, A. Borowik J. Kucharski and M. Kucharski, J. Elemntol., 18, 769 (2012); https://doi.org/10.5601/jelem.2013.18.4.455.
18. I.M. Saianda, C.M.V. Bettencourt, M.C. Queiroga, G. Ferreira-Dias and C.L. Vilela, Rev. Med. Vet. (Toulouse), 158, 362 (2007).

19. R.O. Schneider, C. Diehl, F.M. dos Santos, A.C. Piffer, A.W.A. Garcia, M.I.R. Kulmann, A. Schrank, L. Kmetzsch, M.H. Vainstein and C.C. Staats, Sci. Rep., 5, 10104 (2015); https://doi.org/10.1038/srep10104.

20. T.J.B. Simons, J. Membr. Biol., 123, 63 (1991); https://doi.org/10.1007/BF01993964.

21. C.A. Reid, M.S. Hildebrand, S.A. Mullen, J.M. Hildebrand, S.F. Berkovic and S. Petrou, Br. J. Pharmacol., 174, 119 (2017); https://doi.org/10.1111/bph.13658.

22. P. Singh and A. Nanda, J. Chem. Pharm. Res., 5, 457 (2013).

23. L.S. Cunden, A. Gaillard and E.M. Nolan, Chem. Sci., 7, 1338 (2016); https://doi.org/10.1039/C5SC03655K.

24. V. Sharma, R.K. Shukla, N. Saxena, D. Parmar, M. Das and A. Dhawan, Toxicol. Lett., 185, 211 (2009);

https://doi.org/10.1016/j.toxlet.2009.01.008.

25. H. Akiyama, O. Yamasaki, H. Kanzaki, J. Tada and J. Arata, J. Dermatol. Sci., 17, 67 (1998); https://doi.org/10.1016/S0923-1811(97)00070-4.

26. P. Cervantes-Avilés, E.M.S. Brito, R. Duran, A.B. Martínez and G. Cuevas-Rodríguez, J. Nanopart. Res., 18, 173 (2016); https://doi.org/10.1007/s11051-016-3481-3.

27. A. Loukanov, C. Filipov, V. Valcheva, M. Lecheva and S. Emin, J. Nanopart. Res., 17, 196 (2015); https://doi.org/10.1007/s11051-015-3001-x.

28. T. Bhuyan, M. Khanuja, R. Sharma, S. Patel, M.R. Reddy, S. Anand and A. Varma, J. Nanopart. Res., 17, 288 (2015); https://doi.org/10.1007/s11051-015-3093-3.

29. W. Gao, S. Thamphiwatana, P. Angsantikul and L. Zhang, Wires Nanomed. Nanobiotechnol., 6, 532 (2014); https://doi.org/10.1002/wnan.1282.

30. B. Kataria, V. Shyam, B. Kaushik, J. Vasoya, J. Joseph, C. Savaliya, S. Kumar, S.P. Parikh, C.M. Thakar, D.D. Pandya, A.B. Ravalia, J.H. Markna and N.H. Shah, AIP Conf. Proc., 1837, 040043 (2017); https://doi.org/10.1063/1.4982127.

31. D. Davis and S. Singh, Indian J. Nanosci., 4, 1 (2016).

32. R. Zhao, K. Li, Z. Wang, X. Xing and Y. Wang, J. Phys. Chem. Solids, 112, 43 (2018); https://doi.org/10.1016/j.jpcs.2017.08.039.

33. A.J. Ahamed and P.V. Kumar, J. Chem. Pharm. Res., 8, 624 (2016).

34. S. He, M. Zheng, L. Yao, X. Yuan, M. Li, L. Ma and W. Shen, Appl. Surf. Sci., 256, 2557 (2010); https://doi.org/10.1016/j.apsusc.2009.10.104.

35. Z. Ji, S. Zhao, C. Wang and K. Liu, Mater. Sci. Eng. B: Solid-State Mater. Adv. Technol., 117, 63 (2005); https://doi.org/10.1016/j.mseb.2004.10.016.

36. Z. Kalantari-Bolaghi, S.M. Masoudpanah and M. Hasheminiasari, $J$. Sol-Gel Sci. Technol., 86, 711 (2018); https://doi.org/10.1007/s10971-018-4658-2.

37. K.D. Bhatte, S.I. Fujita, M. Arai, A.B. Pandit and B.M. Bhanage, Ultrason. Sonochem., 18, 54 (2011); https://doi.org/10.1016/j.ultsonch.2010.06.001.

38. M. Darroudi, Z. Sabouri, R. Kazemi Oskuee, A. Khorsand Zak, H. Kargar and M.H.N. Abd Hamid, Ceram. Int., 40, 4827 (2014); https://doi.org/10.1016/j.ceramint.2013.09.032.

39. A. Khorsand Zak, W.H. Abd. Majid, M.R. Mahmoudian, M. Darroudi and R. Yousefi, Adv. Powder Technol., 24, 618 (2013); https://doi.org/10.1016/j.apt.2012.11.008.

40. T. Santhaveesuk, Y. Keawtoakrue, K. Siwawongkasem, and S. Choopun, Key Eng. Mater., 675, 61 (2016); https://doi.org/10.4028/www.scientific.net/KEM.675-676.61. 